\title{
Pembelajaran Literasi Membaca di Pondok Pesantren Sidogiri Kraton Pasuruan
}

\author{
Abdul Muhith* \\ Institut Agama Islam Negeri Jember
}

Keywords:

Learning, Literacy,

Islamic Boarding School

Keywords:

Pembelajaran, Literasi,

Pondok Pesantren.

*Correspondence Address: abdulmuhith1972@gmail.com
Abstract: In the technological and informational era, the people are expected to be able to increase their competence and competitiveness, in such era, competition in all aspects of life is inevitable and humans need precision, determination, trustworthiness, responsibility and dare to face risks from various actions and professions that are chosen, increasing competencies which one of the way to be done wihtin literacy development. The reality of the majority of islamic boarding school graduates is that many of them have not yet reached the minimum competency in the cognitive, affective and psychomotor domains. This can be traced to the many of islamic boarding school graduates who are still not fully mastered in reading books, understanding and completing minimal material. This research was conducted by having the objective to identify the regulation and implementation of reading literacy learning in Islamic boarding schools. This type of research uses field research, with the phenomenology paradigm which takes the case of two islamic boarding schools in East Java, namely the Sidogiri pesantren. Data collection techniques used is depth interviews, participant observation and documentation which is analyzed by using triangulation data validity test, credibility test and extension of involvement, dependability, confirmability and data transferability. The results showed that the regulation of reading literacy learning in Sidogiri Islamic boarding school was planned based on the committee's deliberations under the names of study hours and deliberations which were then consulted with caregivers to obtain approval for its implementation in the form of learning hours, deliberations and independent learning activities.

\begin{abstract}
Abstrak: Era teknologi dan informasi mengharuskan penghuninya untuk meningkatkan kompetensi dan daya saing, pada era tersebut persaingan di segala bidang tak terelakkan dan manusia membutuhkan ketelitian, keteguhan, amanah, tanggung jawab dan berani menghadapi risiko dari berbagai tindakan dan profesi yang menjadi pilihan, peningkatan kompetensi tersebut salah satunya harus dilakukan melalui pengembangan literasi. Realitas mayoritas lulusan pesantren masih banyak yang belum mencapai kompetensi minimal pada ranah kognitif, afektif dan psikomotorik. Hal ini bisa ditelusuri banyaknya lulusan pesantren yang masih belum sepenuhnya menguasai baca kitab, memahami dan menuntaskan materi minimal. Penelitian ini dilakukan dengan tujuan regulasi dan implementasi pembelajaran literasi membaca di pondok pesantren. Jenis penelitian menggunakan field research, dengan paradigma fenomenologi yang mengambil kasus dua pesantren di Jawa Timur yaitu pesantren Sidogiri. Teknik pengumpulan data menggunakan indept interview, observasi partisipan dan
\end{abstract}


dokumentasi. Dengan uji keabahan data trianggulasi, uji kredibilatas dan perpanjangan keterlibatan, dependabilitas, konfirmabilitas dan transferabilitas data. Hasil penelitian menunjukan bahwa regulasi pembelajaran literasi membaca di Pondok Pesantren Sidogiri direncanakan berdasarkan musyarawarah pengurus dengan nama jam belajar dan musyawarah yang kemudian dikonsultasikan kepada pengasuh untuk mendapatkan persetujuan untuk dilaksnakan dan implemenasinya berupa kegiatan jam belajar, musyawarah dan belajar mandiri.

\section{Pendahuluan}

Era teknologi dan informasi mengharuskan penghuninya untuk meningkatkan kompetensi dan daya saing, pada era tersebut persaingan di segala bidang tak terelakkan dan manusia membutuhkan ketelitian, keteguhan, amanah, tanggung jawab dan berani menghadapi risiko dari berbagai tindakan dan profesi yang menjadi pilihan, peningkatan kompetensi tersebut salah satunya harus dilakukan melalui pengembangan literasi. ${ }^{1}$

Realitas mayoritas lulusan pesantren masih banyak yang belum mencapai kompetensi minimal pada ranah kognitif, afektif dan psikomotorik. Hal ini bisa ditelusuri banyaknya lulusan pesantren yang masih belum sepenuhnya menguasai baca kitab, memahami dan menuntaskan materi minimal. ${ }^{2}$

Padahal seharusnya jika sudah dinyatakan lulus dari pondok pesantren, setidaknya para lulusan sudah tuntas pada hal-hal dasar mengenai kemampuan santri seperti membaca kitab yang seharusnya sudah dikuasai dalam waktu tertentu, yang paling ironis kemampuan membaca

1 Dirjen PTKI dan Dirjen Pendis Kemenag RI, Beasiswa 5000 Doktor, 20182019.

2 Dokumen nilai tes baca kitab alumni santri untuk mendapatkan beasiswapemrop Jatim 2012-2014. kitab masih belum mencapai standar minimal pada diri santri yang sudah mondok mencapai tiga tahun $^{3}$ pada saat penulis menjadi penguji tes masuk di beberapa perguruan tinggi (sejak 2003-2018) dan kompetensi mahasiswa pada bidang membaca kitab.

Dalam konteks internasional, literasi membaca sudah dilakukan sejak 2001 sebagaimana pernyataan berikut:

"Pemahaman membaca tingkat sekolah dasar (kelas IV) diuji oleh Asosiasi Internasional untuk Evaluasi Prestasi Pendidikan (IEA-the International Association for the Evaluation of Educational Achievement) dalam Progress in International Reading Literacy Study (PIRLS) yang dilakukan setiap lima tahun (sejak tahun 2001). Selain itu, PIRLS berkolaborasi dengan Trends in International Mathematics and Science Studies (TIMSS) menguji kemampuan Matematika dan Sains peserta didik sejak tahun 2011. Pada tingkat sekolah menengah (usia 15 tahun) pemahaman membaca peserta didik (selain Matematika dan Sains) diuji oleh Organisasi untuk Kerja Sama dan Pembangunan Ekonomi (OECDOrganization for Economic Cooperation and Development) dalam Programme for International Student Assessment (PISA). Uji literasi membaca mengukur aspek memahami, menggunakan, dan

${ }^{3}$ Hasil survey tulisan mahsiswa di lima perguruan tinggi negeri dan swasta lulusan pesantren. 
merefleksikan hasil membaca dalam bentuk tulisan. Dalam PIRLS 2011 International Results in Reading, Indonesia menduduki peringkat ke-45 dari 48 negara peserta dengan skor 428 dari skor rata-rata 500 (IEA, 2012). Sementara itu, uji literasi membaca dalam PISA 2009 menunjukkan peserta didik Indonesia berada pada peringkat ke-57 dengan skor 396 (skor rata-rata OECD 493), sedangkan PISA 2012 menunjukkan peserta didik Indonesia berada pada peringkat ke-64 dengan skor 396 (skor rata-rata OECD 496) (OECD, 2013). Sebanyak 65 negara berpartisipasi dalam PISA 2009 dan 2012. Data PIRLS dan PISA, khususnya dalam keterampilan memahami bacaan, menunjukkan bahwa kompetensi peserta didik Indonesia tergolong rendah.

Dari kedua hasil ini dapat dikatakan bahwa praktik pendidikan yang dilaksanakan di sekolah belum memperlihatkan fungsi sekolah sebagai organisasipembelajaran yang berupaya menjadikan semua warganya menjadi terampil membaca untuk mendukung mereka sebagai pembelajar sepanjang hayat. ${ }^{4}$

Kondisi di Indonesia, kebiasaan membaca masyarakat berada pada peringkat ke-60. Posisi tersebut setingkat dengan negara sedang berkembang seperti Albania (54), Panama (55), dan Botswana (61). ${ }^{5}$

Realitas kurangnya literasi tersebut sangat bertentangan dengan firman Allah yang menganjurkan menusia untuk membaca, sebagaimana firman Allah dalam surat al-'Alaq yang artinya:

\footnotetext{
4 Dewi Utama Faizah dkk, Panduan Literasi (Jakarta: Direktorat Jenderal Pendidikan Dasar dan MenengahKementerian Pendidikan dan Kebudayaan, 2016), iii.

${ }^{5}$ Malaysian National Literacy Survey,
}

1. Bacalah dengan (menyebut) nama Tuhanmu yang menciptakan, 2. Dia telah menciptakan manusia dari segumpal darah. 3. Bacalah, dan Tuhanmulah yang Maha Pemurah, 4. yang mengajar (manusia) dengan perantaran kalam, 5. Dia mengajar kepada manusia apa yang tidak diketahuinya. ${ }^{6}$

Dari beberapa pondok pesantren yang telah melaksanakan pembelajaran literasi (walaupun istilah tersebut tidak dikenal di pesantren) secara sistematis, massif dan terstruktur adalah Pondok Pesantren Sidogiri Kraton Pasuruan.

Fokus penelitian ini adalah bagaimana regulasi pembelajaran literasi membaca di Pondok Pesantren Sidogiri Kraton Pasuruan. Selain itu, penelitian ini juga akan menyuguhkan gambaran tentang proses pelaksanaan pembelajaran literasi membaca bagi santri di Pondok Pesantren Sidogiri Karton Pasuruan.

Secara umum tujuan penulisan dalam penelitian ini adalah untuk memberikan gambaran tentang bagaimana aturan dan proses pelaksanaan literasi membaca khususnya di Pondok Pesantren Sidogiri Kraton Pasuruan.

\section{Tinjauan Teori}

Kegiatan literasi selama ini identik dengan aktivitas membaca dan menulis. Namun, Deklarasi Praha pada tahun 2003 menyebutkan bahwa literasi juga mencakup bagaimana seseorang berkomunikasi dalam masyarakat. Literasi juga bermakna praktik dan hubungan sosial yang terkait dengan pengetahuan, bahasa, dan budaya (UNESCO, 2003).

Deklarasi UNESCO itu juga menyebutkan bahwa literasi informasi terkait pula dengan kemampuan untuk

${ }^{6}$ Al Qur'an, Surah. : 1-5. 
mengidentifikasi, menentukan, menemukan, mengevaluasi, menciptakan secara efektif dan terorganisasi, menggunakan dan mengomunikasikan informasi untuk mengatasi berbagai persoalan. Kemampuankemampuan itu perlu dimiliki tiap individu sebagai syarat untuk berpartisipasi dalam masyarakat informasi, dan itu bagian dari hak dasar manusia menyangkut pembelajaran sepanjang hayat.

Gerakan Literasi Pesantren merupakan suatu usaha atau kegiatan yang bersifat partisipatif dengan melibatkan warga pesantren, akademisi, penerbit, media massa, masyarakat (tokoh masyarakat yang dapat merepresentasikan keteladanan, dunia usaha, dll.), dan pemangku kepentingan di bawah Kementerian Agama RI.

Gerakan Literasipesantren adalah gerakan sosial dengan dukungan kolaboratif berbagai elemen. Upaya yang ditempuh untuk mewujudkannya berupa pembiasaan membaca peserta didik. Pembiasaan ini dilakukan dengan kegiatan 15 menit membaca (guru membacakan buku dan peserta didik membaca dalam hati, yang disesuaikan dengan konteks atau target pesantren). Ketika pembiasaan membaca terbentuk, selanjutnya akan diarahkan ke tahap pengembangan, dan pembelajaran. Variasi kegiatan dapat berupa perpaduanpengembangan keteram-pilan reseptif maupun produktif.

Dalam pelaksanaannya, pada periode tertentu yang terjadwal, dilakukan asesmen agar dampak keberadaan Gerakan Literasi membaca di pesantren dapat diketahui dan terusmenerus dikembangkan.

Literasi lebih dari sekadar membaca dan menulis, namun mencakup keterampilan berpikir menggunakan sumber-sumber pengetahuan dalam bentuk cetak, visual, digital, dan auditori. Di abad 21 ini, kemampuan ini disebut sebagai literasi informasi.

Clay dan Ferguson ${ }^{7}$ menjabarkan bahwa komponen literasi informasi terdiri atas literasi dini, literasi dasar, literasi perpustakaan, literasi media, literasi teknologi, dan literasi visual. Dalam konteks Indonesia, literasi dini diperlukan sebagai dasar pemerolehan berliterasi tahap selanjutnya. Komponen literasi tersebut dijelaskan sebagai berikut:

1. Literasi Dini (Early Literacy), yaitu kemampuan untuk menyimak, memahami bahasa lisan, dan berkomunikasi melalui gambar dan lisan yang dibentuk oleh pengalamannya berinteraksi dengan lingkungan sosialnya di rumah. Pengalaman peserta didik dalam berkomunikasi dengan bahasa ibu menjadi fondasi perkembangan literasi dasar.

2. Literasi Dasar (Basic Literacy), yaitu kemampuan untuk mendengarkan, berbicara, membaca, menulis, dan menghitung (counting) berkaitan dengan kemampuan analisis untuk memperhitungkan (calculating), mempersepsikan informasi (percei-ving), mengomunikasikan, serta menggambarkan informasi (draw-ing) berdasarkan pemahaman dan pengambilan kesimpulan pribadi.

3. Literasi Perpustakaan (Library Literacy), antara lain, memberikan pemahaman cara membedakan bacaan fiksi dan nonfiksi, memanfaatkan koleksi referensi dan periodikal, memahami Dewey Decimal System sebagai klasifikasi pengetahuan yang memudahkan

${ }^{7}$ www.bibliotech.us/pdfs/InfoLit.pdf 
dalam menggunakan perpustakaan, memahami penggunaan katalog dan pengindeksan, hingga memiliki pengetahuan dalam memahami informasi ketika sedang menyelesaikan sebuah tulisan, penelitian, pekerjaan, atau mengatasi masalah.

4. Literasi Media (Media Literacy), yaitu kemampuan untuk mengetahui berbagai bentuk media yang berbeda, seperti media cetak, media elektronik (media radio, media televisi), media digital (media internet), dan memahami tujuan penggunaannya.

5. Literasi Teknologi (Technology Literacy), yaitu kemampuan memahami kelengkapan yang mengikuti teknologi seperti peranti keras (hardware), peranti lunak (software), serta etika dan etiket dalam memanfaatkan teknologi. Berikutnya, kemampuan dalam memahami teknologi untuk mencetak, mempresentasikan, dan mengakses internet. Dalam praktiknya, juga pemahaman menggunakan komputer (Computer Literacy) yang di dalamnya mencakup menghidupkan dan mematikan komputer, menyimpan dan mengelola data, serta mengoperasikan program perangkat lunak. Sejalan dengan membanjirnya informasi karena perkembangan teknologi saat ini, diperlukan pemahaman yang baik dalam mengelola informasi yang dibutuhkan masyarakat.

6. Literasi Visual (Visual Literacy), adalah pemahaman tingkat lanjut antara literasi media dan literasi teknologi, yang mengembangkan kemampuan dan kebutuhan belajar dengan memanfaatkan materi visual dan audiovisual secara kritis dan bermartabat. Tafsir terhadap materi visual yang tidak terbendung, baik dalam bentuk cetak, auditori, maupun digital (perpaduan ketiganya disebut teks multimodal), perlu dikelola dengan baik. Bagaimanapun di dalamnya banyak manipulasi dan hiburan yang benarbenar perlu disaring berdasarkan etika dan kepatutan.

Menurut Beers $^{8}$, praktik-praktik yang baik dalam gerakan literasi sekolah menekankan prinsip-prinsip sebagai berikut.

1. Perkembangan literasi berjalan sesuai tahap perkembangan yang dapat diprediksi. Tahap perkembangan anak dalam belajar membaca dan menulis saling beririsan antartahap perkembangan. Memahami tahap perkembangan literasi peserta didik dapat membantu sekolah untuk memilih strategi pembiasaan dan pembelajaran literasi yang tepat sesuai kebutuhan perkembangan mereka.

2. Program literasi yang baik bersifat berimbang Sekolah yang menerapkan program literasi berimbang menyadari bahwa tiap peserta didik memiliki kebutuhan yang berbeda. Oleh karena itu, strategi membaca dan jenis teks yang dibaca perlu divariasikan dan disesuaikan dengan jenjang pendidikan. Program literasi yang bermakna dapat dilakukan dengan memanfaatkan bahan bacaan kaya

${ }^{8}$ Beers, C. S., Beers, J. W., \& Smith, J. O. A Principal's Guide to Literacy

Instruction. (New York: Guilford Press. 2009), 23 
ragam teks, seperti karya sastra untuk anak dan remaja.

3. Program literasi terintegrasi dengan kurikulum Pembiasaan dan pembelajaran literasi di sekolah adalah tanggung jawab semua guru di semua mata pelajaran sebab pembelajaran mata pelajaran apapun membutuhkan bahasa, terutama membaca dan menulis. Dengan demikian, pengembangan profesional guru dalam hal literasi perlu diberikan kepada guru semua mata pelajaran.

4. Kegiatan membaca dan menulis dilakukan kapanpun Misalnya, 'menulis surat kepada presiden' atau 'membaca untuk ibu' merupakan contoh-contoh kegiatan literasi yang bermakna.

5. Kegiatan literasi mengembangkan budaya lisan Kelas berbasis literasi yang kuat diharapkan memunculkan berbagai kegiatan lisan berupa diskusi tentang buku selama pembelajaran di kelas. Kegiatan diskusi ini juga perlu membuka kemungkinan untuk perbedaan pendapat agar kemampuan berpikir kritis dapat diasah. Peserta didik perlu belajar untuk menyampaikan perasaan dan pendapatnya, saling mendengarkan, dan menghormati perbedaan pandangan.

6. Kegiatan literasi perlu mengembangkan kesadaran terhadap keberagaman.. Bahan bacaan untuk peserta didik perlu merefleksikan kekayaan budaya Indonesia agar mereka dapat terpajan pada pengalaman multikultural.

Agar pesantren mampu menjadi garis depan dalam pengembangan budaya literasi, Beers, dkk. ${ }^{9}$ (2009) dalam buku $A$ Principal's Guide to Literacy Instruction, menyampaikan beberapa strategi untuk menciptakan budaya literasi yang positif di sekolah.

1. Mengkondisikan lingkungan fisik ramah literasi Lingkungan fisik adalah hal pertama yang dilihat dan dirasakan warga sekolah. Oleh karena itu, lingkungan fisik perlu terlihat ramah dan kondusif untuk pembelajaran. Sekolah yang mendukung pengembangan budaya literasi sebaiknya memajang karya peserta didik dipajang di seluruh area sekolah, termasuk koridor, kantor kepala sekolah dan guru. Selain itu, karyakarya peserta didik diganti secara rutin untuk memberikan kesempatan kepada semua peserta didik. Selain itu, peserta didik dapat mengakses buku dan bahan bacaan lain di Sudut Baca di semua kelas, kantor, dan area lain di sekolah. Ruang pimpinan dengan pajangan karya peserta didik akan memberikan kesan positif tentang komitmen sekolah terhadap pengembangan budaya literasi.

2. Mengupayakan lingkungan sosial dan afektif sebagai model komunikasi dan interaksi yang literat Lingkungan sosial dan afektif dibangun melalui model komunikasi dan interaksi seluruh komponen sekolah. Hal itu dapat dikembangkan dengan pengakuan atas capaian peserta didik sepanjang tahun. Pemberian penghargaan dapat dilakukan saat upacara bendera setiap minggu untuk menghargai kemajuan

${ }^{9}$ Beers, C. S., Beers, J. W., \& Smith, J. O. A Principal's Guide...., 36 
peserta didik di semua aspek. Prestasi yang dihargai bukan hanya akademik, tetapi juga sikap dan upaya peserta didik. Dengan demikian, setiap peserta didik mempunyai kesempatan untuk memperoleh penghargaan sekolah. Selain itu, literasi diharapkan dapat mewarnai semua perayaan penting di sepanjang tahun pelajaran. Ini bisa direalisasikan dalam bentuk festival buku, lomba poster, mendongeng, karnaval tokoh buku cerita, dan sebagainya. Pimpinan sekolah selayaknya berperan aktif dalam menggerakkan literasi, antara lain dengan membangun budaya kolaboratif antarguru dan tenaga kependidikan. Dengan demikian, setiap orang dapat terlibat sesuai kepakaran masingmasing. Peran orang tua sebagai relawan gerakan literasi akan semakin memperkuat komitmen sekolah dalam pengembangan budaya literasi.

3. Mengupayakan sekolah sebagai lingkungan akademik yang literat Lingkungan fisik, sosial, dan afektif berkaitan erat dengan lingkungan akademik. Ini dapat dilihat dari perencanaan dan pelaksanaan gerakan literasi di sekolah. Sekolah sebaiknya memberikan alokasi waktu yang cukup banyak untuk pembelajaran literasi. Salah satunya dengan menjalankan kegiatan membaca dalam hati dan guru membacakan buku dengan nyaring selama 15 menit sebelum pelajaran berlangsung.

Untuk menunjang kemampuan guru dan staf, mereka perlu diberikan kesempatan untuk mengikuti program pelatihan tenaga kependidikan untuk peningkatan pemahaman tentang program literasi, pelaksanaan, dan keterlaksanaannya.

Program Gerakan Literasi Sekolah dilaksanakan secara bertahap dengan mempertimbangkan kesiapan sekolah di seluruh Indonesia. Kesiapan ini mencakup kesiapan kapasitas sekolah (ketersediaan fasilitas, bahan bacaan, sarana, prasarana literasi), kesiapan warga sekolah, dan kesiapan sistem pendukung lainnya (partisipasi publik, dukungan kelembagaan, dan perangkat kebijakan yang relevan).

1. Definisi Literasi

Literasi secara tradisional diartikan dengan kemampuan membaca dan menulis, seseorang dipandang sebagai literat menurut pendapat ini adalah mereka yang dapa membaca dan menulis atau terbebas dari buta huruf. Kemudian istilah literasi mengalami perkembangan sesuai perjalanan waktu sehingga merambah ke berbagai bidang. Definisi literasi dalam konteks Gerakan Litersi Sekolah adalah kemampuan mengakses, memahami, dan menggunakan sesuatu secara cerdas melalui berbagai aktivitas, antara lain membaca, melihat, menyimak, menulis, dan atau berbicara. ${ }^{10}$

Sedangkan perkembangan arti dipengaruhi oleh beberapa hal, antara lain:
a. Penggunaan istilah literasi dalam arti luas
b. Perkembangan imformasi dan teknologi
c. Perubahan analogi, dan
d. Perkembangan konsep antar generasi. $^{11}$

10 Dewi Utama Faizah DKK, Panduan Literasi....2.

11Yunus Abidin, Tita Mulyai dan Hana Yunansah, Pembelajaran Literasi Staretegi 
Selanjutnya konsep literasi sesuai masa perkembangannya dapat difahami sebagai berikut:

a. Masa perkembangan awal

Literasi pada pada masa adalah kemampuan untuk menggunakan bahasa gambar dalam bentuk yang kaya dan beragam untuk membaca menulis, mendengarkan, berbicara, melihat, menyajikan dan kritis dalam berfikir mengenai berbagai ide ${ }^{12}$.

b. Masa perkembangan kedua

Leterasi pada masa ini merupakan praktik sosial dan budaya berupa keyakinan budaya dan habitualnya. Dalam pandangan ini literasi ditafsirkan oleh para ahli dengan menghubungkan pada konteks dunia, yang ditekankan pada proses pengembangan literasi siswa dan pendekatan yang digunakan untuk memahami beberapa bidang akademik ${ }^{13}$.

c. Masa perkembangan ketiga

Di era ini, pengertian literasi adalah kemampuan menggunakan teknologi informasi untuk membaca dan menulis di internet melalui multimedia modalitas yang memutuhkan cara yang bervariasi pada saat berinteraksi dengan teks. ${ }^{14}$

d. Masa perkembangan keempat Pada perkembangan keempat ini literasi dianggap sebagai kontruksi sosial dan tidak netral, artinya semua

\footnotetext{
meningkatkan Kemampuan Literasi

Matematika, Sain, membaca dan Menulis

(Jakarta: Bumi Aksara, 2017),1.

12Yunus Abidin DKK, Literasi....1.

13Yunus Abidin DKK, Literasi....2.

${ }^{14}$ Yunus Abidin DKK, Literasi....2.
}

teks buku yang dibaca peserta didik sudah diposisikan oleh penulis sesuai dengan posisi mereka yang meliputi keyakinan, nilai yang ditanamkan, sosial budaya dan pengalamannya. ${ }^{15}$

e. Masa perkembangan kelima

Konsep literasi pada generasi kelima sudah dikenal dengan konsep multiliterasi, yaitu kemampuan untuk dapat menggunakan beberapa cara untuk mengungkapkan dan memperoleh pemhaman tentang berbagai ide dan informasi yang berbentuk teks konfensional maupun teks yang telah diinovasi, simbol maupun multimedia. ${ }^{16}$

2. Pembelajaran Literasi Membaca

Pembelajaran

literasi membaca kemudian diperkuat oleh Gerakan Literasi Sekolah (GSL) yang mengacu kepada sembilan agenda prioritas (NAWACITA). Di dalam Nawacita ditegaskan bahwa:

"GLS yang dikembangkan berdasarkan sembilan agenda prioritas (Nawacita) serta terkait dengan tugas dan fungsi Kemendikbud, khususnya Nawacita nomor 5 , 6, 8, dan 9. Butir Nawacita yang dimaksudkan adalah (5) meningkatkan kualitas hidup manusia dan masyarakat Indonesia; (6) meningkatkan produktivitas rakyat dan daya saing di pasar internasional sehingga bangsa Indonesia bisa maju dan bangkit bersama bangsa-bangsa Asia

15Yunus Abidin DKK, Literasi....2-3.
16Yunus Abidin DKK, Literasi....3. 
lainnya; (8) melakukan revolusi karakter bangsa; (9) memperteguh kebinekaan dan memperkuat restorasi sosial Indonesia. Empat butir Nawacita tersebut terkait erat dengan komponen literasi sebagai modal pembentukan sumber daya manusia yang berkualitas dan produktif. Panduan Gerakan Literasi Sekolah di sekolah dasar dan berdaya saing, berkarakter, serta nasionalis. ${ }^{17}$

3. Implementasi Literasi di Pesantren

Abad 21 memberikan tawaran pendidikan yang menjajikan berbagai pendekatan pembelajar diyakini keampuhan kontribusinya terhadap pengembangan kompetensi peserta didik, baik pada ranah keilmuan, sikap maupun ketrampilan. Diantara pendekatan-pendekatan pembelajaran tersebut adalah pendekatan integratif, pendekatan ini pertama kali diterapkan pada kelas rendah di sekolah dasar, akan tetapi dampak positif dari pendekatan tersebut sangat dirasakan sangat dominan, kemudian menjadi trend dan layak untuk menjadi alternatif rekayasa pembelajaran, sehingga direkomendasikan untuk dapat diterapkan pada seluruh jenjang pada pendidikan dasar yang dikembangkan dalam pembelajaran interdisipliner, kemudian pembelajaran integratif diinovasi dalam beberapa konteks, salah satu konteks tersebut adalah konsep literasi, karena realitas

17 Dewi Utama Faizah, Panduan Literasi....1-2. multiliterasi merupakan perpaduan beberapa disiplin ilmu dengan konsep literasi. ${ }^{18}$

Selanjutnya pembelajaran integratif menurut Forgati adalah Pembelajaran yang memadukan kurikulum dalam berbagai bentuk pemaduan materi pembelajaran, pemaduan pengalaman belajar serta pemaduan keterampilan, tema, konsep, dan topik lintas disiplin ilmu. ${ }^{19}$

$$
\text { Implementasi literasi di }
$$
pesantren sebenarnya sudah lama dilakukan, hanya saja tidak disebutkan dengan istilah literasi, berbeda dengan di sekolah atau madrasah, gerakan literasi diperkuat oleh GSL yaitu sebuah upaya yang dilakukan secara menyeluruh untuk menjadikan sekolah sebagai organisasi pembelajaran yang warganya literat sepanjang hayat melalui pelibatan publik. $^{20}$ Literasi di pesantren tersebut dimulai dari literasi baca dan tulis. Literasi tersebut dapat diuraikan sebagai berikut:

a. Konsep literasi membaca di pesantren

Konsep literasi membaca merupakan usaha memahami, menggunakan, merefleksikan, dan melibatkan diri dalam berbagai teks untuk mencapai maksud yang dituju. Sedangkan maksud literasi membaca adalah mengembangkan pengetahuan, potensi dan peran serta dalam masyarakat yang didasarkan dari pemahaman dari teks

${ }^{18}$ Yunus Abidin DKK, Literasi....66.

${ }^{19}$ Forgaty,1991, How To Integrated Curriculum dalam Yunus Abidin DKK, Literasi....67.

20 Dewi Utama Faizah, Panduan Literasi.... 2. 
yang dibaca secara utuh. Dengan kata lain aktivitas membaca merupakan aktivitas membangun arti dari sebuah informasi yang dibaca secara nyata dalam kehidupan yang difahami secara utuh. ${ }^{21}$

b. Tujuan Literasi

Literasi memiliki tujuan sebagai berikut:

1) Tujuan Umum Menumbuhkemban g-kan budi pekerti peserta didik melalui pembudayaan ekosistem literasi sekolah yang diwujudkan dalam Gerakan Literasi Sekolah agar mereka menjadi pembelajar sepanjang hayat. $^{22}$

2) Tujuan Khusus

a) Menumbuhkembangk an budaya literasi di sekolah.

b) Meningkatkan kapasitas warga dan lingkungan sekolah agar literat.

c) Menjadikan sekolah sebagai taman belajar yang menyenangkan dan ramah anak agar warga sekolah mampu mengelola pengetahuan.

d) Menjaga keberlanjutan pembelajaran dengan menghadirkan beragam buku bacaan dan mewadahi

$\begin{array}{lr}\text { berbagai strategi } & \\ \text { membaca. } & \\ \text { Begitu pula tujuan } \\ \text { khusus } & \text { dari } \\ \text { pembelajaran literasi } \\ \text { di pesantren agar } \\ \text { pembelajaran literasi } \\ \text { menjadi budaya } \\ \text { pesantren, menjadi } \\ \text { santri yang literat, } \\ \text { pesantren menjadi } \\ \text { taman belajar dan } \\ \text { meningkatkan } \\ \text { kemampuan untuk } \\ \text { membaca referensi } \\ \text { yang lebih luas dan } \\ \text { mendalam. }\end{array}$

c. Teks yang Dibaca

Jenis teks yang dibaca sangat bervariasi, bisa berupa media, format atau lingkungan. Pada lembaga pesantren teks yang dibaca mulai dari kitab klasik sampai dengan kitab atau buku kontemporer.

d. Pemahaman Teks

Pemahaman terhadap teks memilki tingkatan yang berbeda, mulai dari pemahaman sederhana hingga pemahaman yang kompleks. Kemampuan pemahaman yang dibutuhkan lebih kompleks adalah upaya merefleksikan, mengevaluasi teks yang dibaca dan mengasosiasikan teks dengan pengalaman pembaca.

e. Situasi Sosial

Situasi sosial mengharuskan pembaca untuk memahami maksud penulis sebuah teks, pilihan kalimat, personal, lingkungan yang mempengaruhi, tingkatan pen-

21Yunus Abidin DKK, Literasi....165.

22. Dewi Utama Faizah, Panduan Literaai.... 2. Literaai.... 2.

23 Dewi Utama Faizah, Panduan 
didikan dan profesi yang ditekuni24.

f. Pembelajaran Literasi Membaca

Pembelajaran didefinisikan sebagai serangkaian proses yang dilakukan guru agar siswa belajar. Pembelajaran membaca merupakan serangkaian aktivitas yang dilakukan siswa untuk mencapai keterampilan membaca pemahaman yang melibatkan seluruh aktivitas mental dan kompetensi berfikir peserta didik untuk memahami, mengkritisi dan menghasilkan sebuah wacana tertulis. Agar dapat menghasilkan pemahaman yang mendalam, kegiatan membaca harus dimulai dengan pertanyaan tingkat tinggi, dengan menggunakan kata tanya mengapa dan bagaimana, untuk menjawab pertanyaan tersebut pembaca hendaknya menganalisis teks, membuat inferensi, mengevaluasi teks, dan jawaban dibuktikan dengan kutipan teks tersebut. ${ }^{25}$

g. Prosedur Pembelajaran Literasi Membaca

Agar pembelajaran literasi membaca dapat memperoleh pemahaman yang mendalam, maka aktifitas peserta didik diarahkan untuk:

1) Menganalisis kandungan teks, baik yang bersifat implisit atau eksplisit

2) Memberikan gambaran inferensi analitis terhadap teks yang dibaca
3) Menanggapi teks secara kritis dengan menggunakan cara berfikir rasional yang ditunjang oleh bukti otentik secara lengkap baik dari dalam teks maupun dari luar teks

4) Menghasilkan pemahaman secara kreatif dengan menggunakan berbagai media yang bersifat multimodal, multi genre, multimedia dan ragam budaya.

Untuk mencapai tujuan pembelajaran literasi membaca, dalam membina budaya dan kemampuan membaca, aktivitas pembelajaran literasi membaca harus menggunakan tiga tahapan aktivitas, yaitu:

h. Aktivits pra membaca

Guru harus dapat mengarahkan kegiatan peserta didik untuk menciptakan pembelajaran yang efektif, upaya guru tersebut dalam aktivitas pra baca harus mengkondisikan kegiatan siswa sebelum membaca dengan mengaktifkan skemata peserta didik yang berkaitan dengan teks yang akan dibaca. Skemata merupakan latar belakang pengetahuan dan pengalaman yang dimiliki peserta didik tentang suatu informasi atau konsep yang berhubungan dengan objek, tempat, tindakan atau peristiwa. $^{26}$

Aktivitas pramembaca merupakan rencana yang dilakukan guru dengan atau tanpa melibatkan peserta didik dalam perencanaanya. 
Alasan tersebut sejalan dengan pendapat para ahli tentang pendekatan respon membaca yang mengatakan bahwa pramembaca adalah aktivitas perencanaan membaca yang dilakukan guru, aktivitas guru tersebut antara lain adalah: mengidentifikasi teks, menetapkan tujuan membaca, menyusun pertanyaan yang terikat dengan teks, menyiapkan teks untuk kegiatan membaca dan memilih model teks yang akan digunakan dalam pembelajaran. ${ }^{27}$ Sedangkan pendapat ahli yang menyatakan bahwa aktivitas pramembaca merupakan upaya membangkitkan skemata yang dimiliki peserta didik. Dengan demikian aktivitas pramembaca yang meliputi: membangkitkan pengetahuan awal, membuat prediksi isi bacaan, menetapkan strategi prabaca, menebak isi bacaan, curah pendapat dan mengembangkan peta konsep. ${ }^{28}$

i. Aktivitas Membaca Setelah melakukan aktivitas prabaca, selanjutnya melakukan aktivitas membaca, pada tahap membaca berbagai variasi yang dilaksanakan guru sesuai dengan strategi membaca yang dipilih guru atau peserta didik. Aktifitas membaca yang harus dilakukan guru dan peserta didik adalah sebagai berikut:

${ }^{27}$ Lapp et.al (2015) dalam Yunus Abidin DKK, Literasi....184.

28 Moreillon et.al ( 200: 11) dalam Yunus Abidin DKK, Literasi....185. a) Aktifitas membaca yang dilakukan guru adalah: menayangkan teks terkait yang dibaca peserta didik; mendorong aktivitas percakapan yang penuh makna dan berhubungan dengan teks untuk mencapai tujuan pembelajaran; memantau siswa dalam kegiatan mereka baik saat berbicara dan menulis sebagai bentuk respon dalam mengidentifikasi pertanyaan yang diperlukan dan menjadi pertanyaan berikutnya; mendorong peserta didik membaca ulang sehingga mereka dapat menganalisis secara mendalam teks yang dibaca; mengamati aktivitas siswa dalam membaca ulang untuk menyusun pertanyaan agar mereka dapat menganalisis lebih mendalam dan memberikan inisiatif yang lebih tepat untuk dapat dilakukan oleh peserta didik melalui diskusi, kolaborasi dan sikap kooperatif untuk berbagi pemahaman; dan informasi dengan peserta didik yang lain.

b) Aktivitas membaca yang harus dilakukan peserta didik adalah: membaca teks, menganalisis dan mengutip teks untuk maksud tertentu; telibat secara aktif dalam percakapan, mencatat, dan konsentrasi penuh tertuju 
pada fokus yang selaras dengan tujuan pembelajaran; mengulang bacaan dengan tujuan memperluas dan mendalami pemahaman terhadap teks; berbagi informasi dengan peserta siswa lain; membaca kembali; dan melanjutkan kegiatan kolaboratif sampai mendapatkan pemahan yang mendalam fitur dan maksud teks yang digagas oleh penulis teks tersebut. ${ }^{29}$

c) Aktivitas pascamembaca Setelah melakukan aktivitas membaca, kegiatan yang harus dilakukan adalah: menuliskan kembali teks yang dibaca; membandingkan bacaan dengan teks lain; melakukan dramatisasi pesan teks; menggambarkan gagasan teks, membuat alat peraga untuk menceritakan teks yang dibaca; melakukan penelitian untuk memperkaya topik yang dibaca; melakukan wawancara dengan informan terkait; dan mebuat diorama cerita yang dibaca. ${ }^{30}$

j. Metode dan Strategi Pembelajaran Literasi Membaca Implementasi pembelajaran literasi membaca dapat dilakukan melalui kreativitas guru dan peserta didik dengan menggunkan

${ }^{29}$ Sisson (2014) dalam Yunus Abidin DKK, Literasi....187-188.

${ }^{30}$ Yunus Abidin DKK, Literasi....183. metode yang sesuai dan efektif. Di antara metode yang dapat dilakukan dalam pembelajaran literasi adalah:

1) Metode Membaca cermat Multiliterasi

Metode ini dikembangkan dari konsepsi yang menggabungkan membaca cermat dalam pandangan respon pembaca dengan membaca pemahaman dalam pandangan teori konstruktivistik, metode ini sesuai untuk tema sejarah, ilmu sosial dan teks pendidikan kewarganegaraan.

2) Metode Pembalajaran Inkuiri Membaca Konteks membaca inkuri adalah sebuah aktivitas meneliti suatu teks untuk memperoleh makna yang temuat dalam teks tersebut.

3) Metode Eksplorasi Masalah Matematis

Metode ini adalah bentuk pemecahan masalah dalam Matematika yang berbentuk cerita.

4) Metode SQ3R untuk Ilmu Sosial

Metode ini adalah metode pembelajaran dengan menggunakan lima langkah, yaitu survey (mengamati), quetion (bertanya), read (membaca), dan review (mengulas).

d) Metode PQRST Untuk Teks Ilmu Sains

Metode ini adalah metode pembelajaran membaca melalui: preview (peninjauan), question (pertanyaan), read (membaca), 
summary (merngkum), dan tes (ujian). ${ }^{31}$

\section{Metode Penelitian}

\section{Pendekatan Penelitian}

Penelitian ini menggunakan metode penelitian kualitatif jenis studi kasus yang bersifat deskriptif. Menurut Sugiyono metode penelitian kualitatif adalah metode yang digunakan untuk meneliti pada kondisi objek yang alamiah dimana peneliti sebagai instrument kunci. ${ }^{32}$

Penelitian ini menggunakan pendekatan kualitatif yang bersifat deskriptif karena; pertama, tujuan penelitian ini akan menggambarkan realitas yang kompleks dengan menetapkan penelitian berdasarkan keseluruhan situasi di dalam lingkungan sekolah, ruang kelas, termasuk di dalamnya guru, murid, serta aktivitas pembelajaran. Kedua, penelitian ini dilakukan dalam situasi alamiah dan cara alamiah dimana peneliti termasuk instrument kunci dan tidak membuat perlakuan khusus dalam penelitian. Ketiga, data yang terkumpul akan banyak berbentuk kata-kata, gambar, tulisan, sehingga tidak menekankan pada angka.

\section{Metode Pengumpulan Data}

Untuk memperoleh data yang dibutuhkan, peneliti akan menggunakan metode pengumpulan data yang meliputi:

a. Metode Observasi Partisipatif Sugiyono mengatakan bahwa dalam observasi partisipatif,

31 Yunus Abidin DKK, Literasi....183.

${ }^{32}$ Sugiyono, Metode Penelitian Kuantitatif Kualitatif dan $R$ \& $D$, (Bandung: Alfabeta, 2007),15. peneliti mengamati apa yang dikerjakan orang, mendengarkan apa yang mereka ucapkan, dan berpartisipasi dalam aktivitas mereka. ${ }^{33}$

Selama interaksi, penulis akan mengamati secara langsung segala sesuatu khususnya tentang pelaksanaan literasi membaca di pondok pesantren Sidogri

b. Wawancara Terstruktur dan Semiterstruktur.

Wawancara ini akan penulis mulai dari sumber data pertama yaitu, pengasuh pondok pesantren, Ustadz dan santri Pondok Pesantren Sidogiri mengenai persiapan, pelaksanaan dan evaluasi literasi membaca.

c. Metode Dokumentasi

Data dari hasil observasi dan wawancara dalam penelitian ini akan penulis lengkapi dengan penelitian terhadap data fisik berupa dokumen yang terkait dengan fokus penelitian.

d. Analisis Data

Data yang telah diperoleh melalui observasi partisipatif, wawancara terstruktur, indepth interview, dan dokumentasi dalam penelitian ini akan dianalisis menggunakan model Miles dan Hubermen. Aktivitas dalam analisis data model Miles dan Hubermen meliputi data reduction (reduksi data), data display (penyajian data), conclution drawing/verification. ${ }^{34}$

Langkah-langkah analisis data dalam penelitian ini meliputi:

1) Reduksi Data.

${ }^{33}$ Sugiyono, Metode Penelitian Kuantitatif Kualitatif dan $R$ \& D, (Bandung: Alfabeta, 2007). 311

${ }^{34}$ Sugiyono, Metode Penelitian Kuantitatif Kualitatif dan R \& D, (Bandung: Alfabeta, 2007), 337. 
Reduksi tersebut terkait dengan data-data hasil observasi partisipatif, wawancara terstruktur, indepth interview, dan dokumentasi yang berhubungan dengan metode literasi membaca.

2) Penyajian Data

Setelah melakukan reduksi data, selanjutnya peneliti menyajikan data melalui uraian singkat yang bersifat naratif sehingga memudahkan untuk memahami permasalahan dan memudahkan rencana kerja selanjutnya.

3) Penarikan Kesimpulan dan Verifikasi

Kegiatan dalam langkah ketiga ini adalah menarik kesimpulan dan verifikasi terhadap hasil penelitian. Dari kesimpulan dan verifikasi ini diketahui pelaksanaan kegiatan literasi membaca.

\section{Hasil dan Pembahasan}

\section{Pembelajaran Literasi Membaca di Pesantren Sidogiri}

Pembelajaran lieterasi membaca di Pesantren Sidogiri pada awalnya dilakukan secara alami. Akan tetapi selanjutnya dilakukan melalui dua fokus utama, yaitu diprogramkan dalam sebuah peraturan (regulasi) dan implementasi.

a. Regualasi pembelajaran literasi membaca di Pondok Pesantren Sidogiri

Regulasi atau peraturan pembelajaran literasi membaca di Pondok Pesantren Sidogiri dilakukan melalui perencanaan yang dimusyawarhkan oleh pengurus pondok pesantren untuk menetapkan peraturan terkait pelaksanaan mengenai nama yaitu jam belajar dan musyawarah, waktu, tempat, monitoring dan konsekuensi yang tidak mengikuti peraturan tersebut, kemudian dikonsultasikan kepada pengasuh, setelah disetujuai oleh pengasuh kemudian ditetapkan untuk dilaksanakan.

b. Implementasi pembelajaran literasi membaca di Pondok Pesantren Sidogiri

Implementasi pembelajaran literasi membaca di Pondok Pesantren Sidogiri adalah sebagai berikut:

\section{Kegiatan jam belajar}

Kegiatan jam belajar lamanya dua jam, yaitu dimulai dari pukul 21.00-22.00 dan pada pukul 05.0006.00, yang wajib diikuti oleh semua santri, sedangkan materi yang dibaca adalah pelajaran mereka sesuai dengan tingkatan, pada kegiatan tersebut seluruh santri membaca pelajaran sesuai gaya membaca mereka, baik nyaring maupun senyap. Kegiatan tersebut di-monitoring oleh pengurus daerah dan pengurus pesantren, sehingga seluruh santri tidak boleh tidur atau ngobrol yang tidak ada kaitannya dengan belajar.

2. Musyawarah

Pembelajaran literasi selanjutnya dilakukan dengan kegiatan musyawarah, semua santri wajib mengikuti kegiatan musyawarah sesuai dengan kelasnya mulai dari level ibtidaiyah sampai tsanawiyah, kegiatan musya-warah dimaksud adalah mengulang kembali pelajaran yang sudah diperoleh di kelas dari ustadz, kemudian diterangkan lagi oleh temannya yang memiliki kemampuan lebih, sebagai tutor sebaya. 
3. Membaca sendiri di kamar atau perpustakaan sesuai waktu dan materi yang disukai santri.

\section{Kesimpulan}

Regulasi pembelajaran literasi membaca di Pondok Pesantren Sidogiri direncanakan berdasarkan musyarawarah pengurus dengan nama jam belajar dan musyawarah yang kemudian dikonsultasikan kepada pengasuh untuk mendapatkan persetujuan untuk dilaksnakan. Sementara itu, implementasi pembelajaran literasi membaca di Pondok Pesantren Sidogiri dilakukan dengan tiga kegiatan. Pertama, jam belajar dilaksanakan satu jam di malam hari dan satu jam di pagi hari di daerah atau asrama santri, yang harus diikuti oleh semua santri dan diawasi oleh pengurus. Kedua, musyawarah yang diikuti oleh santri tingkat Madrasah Ibtidaiyah dan Tsanawiyah, sedangkan materinya adalah pelajaran di kelas. Ketiga, membaca sendiri baik di perpustakaan maupun di kamar masing-masing, dengan materi yang disukai.

\section{Referensi}

Abidin, Yunus, Tita Mulyai dan Hana Yunansah, Pembelajaran Literasi Strategi meningkatkan Kemampuan Literasi Matematika, Sain, Membaca dan Menulis, Jakarta: Bumi Aksara, 2017.

Beers, J. W., \& Smith, J. O., A Principal's Guide to Literacy Instruction, New York: Guilford Press, 2009.

Bogdan, Robert, and Steven J. Taylor, Introduction to Qualitative Research Methods, Terjemahan Arief Furhan, Surabaya: Usaha Nasional, 1992.

Bungin, Burhan, Analisis Data Penelitian Kualitatif, Jakarta: Raja Grafindo Persada, 2005.
Central Connecticut State University, World's Most Literate Nations. Diakses pada 13 Februari 2018 diakses darihttps://webcapp.ccsu.edu/?n ews $=1767 \&$ data.

Debdikbud, Kamus Besar Bahasa Indonesia, Jakarta : Bulan Bintang, 2002.

Debdikbud, Kamus Besar Bahasa Indonesia, Jakarta: Balai Pustaka, 2001.

Depag RI, Al-Qur'an dan Terjemahnya, Surabaya: Duta Ilmu, 2002.

Djamarah, Syaiful Bahri, Guru dan Anak Didik, Jakarta: Rineka Cipta, 2010.

Faisal, Sanapiah, Penelitian Kualitatif: Dasar-Dasar dan Aplikasi, Malang: YA3, 1990.

Faizah, Dewi Utama, et.al., Panduan Literasi Sekolah di SD, Jakarta: Direktorat Jenderal Pendidikan Dasar dan MenengahKementerian Pendidikan dan Kebudayaan, 2016.

Imron Arifin,1996, Penelitian Kualitatif dalam Ilmu-Ilmu Sosial dan Keagamaan Malang Kalima sada Perss.

Junaidi \& Fauzan, Metodologi Penelitian Kualitatif , Jogjakarta: Amera, 2012.

Mudzakir, Studi Kasus: Desain dan Metode Jakarta: PT. RajaGrafindo Persada, 2014.

Muslich, M., Melaksanakan PTK itu Mudah, Jakarta: Bumi Aksara, 2009.

Robert C. Bogdan dan Sari Knoop Biklen, Qualitative Research For Education: An Intrudution to Theory and Methods, Buston: Aliyin and Bacon, 1998.

Silalahi, Amin, Metodologi Penelitian Studi Kasus, Sidoarjo: Citramedia, 2003. 
Siregar, Eveline dan Hartini Nara, Teori Belajar dan Pembelajaran, Bogor: Ghalia Indonesia, 2011.

Sugiyono, Metode penelitian kuantitatif, kualitatif, dan $R$ \& D. Bandung: Alfabeta, 2012.

Sugiyono. Metode Penelitian Kuantitatif, kualitatif, dan $R$ \& D. Bandung: Alfabeta, 2012.

Undang-Undang No. 20 Tahun 2003 tentang Sistem Pendidikan Nasional.

Wiedarti, Pangesti, et.al., Desain Induk Gerakan Literasi Sekolah, Jakarta: Direktorat Jenderal Pendidikan Dasar dan MenengahKementerian Pendidikan dan Kebudayaan, 2016.

Worsley, Peter, Introducing Sociology, England: Penguin Books, 1970.

Yin, Robert K., Case Study Research: Design and Methods, diterjemahkan oleh M. Djauzi, Jakarta: Rajawali, 2008. 